\title{
Effectiveness of Digital Media Education on the Attitude of the Diabetic Patients
}

\author{
G. Padmini Devi* \\ Government College for Women (A), Guntur, India \\ *Corresponding author
}

\section{Keywords}

Diabetic patients, Digital media education

\section{Article Info}

Accepted:

10 August 2020

Available Online:

10 September 2020

\begin{abstract}
A B S T R A C T
Early detection and effective treatment protocol is the key to minimize the complications associated with a lifestyle disorder like diabetes. So, educating the patients through digital media will enable us to bring desirable change in the attitude of diabetic patients. With this backdrop, the present paper aimed to assess the effectiveness of digital media content on the attitude of the diabetic patients. An exploratory research design with two hundred type2 diabetes respondents were selected randomly from the rural and urban areas of Guntur district of Andhra Pradesh. A two months education program based on digital media content in different forms like 90 text, 30 voice messages, and 8 animation modules was developed and disseminated. After the education program, post-intervention changes in the attitude of the respondents measured with a time gap of two months. The major findings of the study revealed that there was a significant difference in the overall attitude of the respondents between pre and post-intervention. Further, the respondents had significant progress of positive attitude towards clinical attitude with a percent increase of $23.17 \%$ followed by nutrition attitude $(20.71 \%)$ and management attitude (10\%) after postintervention. Thus, digital media plays an impressive role in changing the attitude of the diabetic patients.
\end{abstract}

\section{Introduction}

Diabetes is a chronic metabolic disorder with the highest prevalence around the globe for the past few decades and India becomes the world diabetic capital with its highest number next to china. Yet, despite the high incidence of the disease in India people's awareness of the disease is nominal. This lack of knowledge about various aspects of the disease may result in multiple complications in the long run. Hence, early detection and effective treatment protocol is the key to minimize the complications associated with a lifestyle disorder like diabetes. It is possible only with the patient's active involvement by regular self-monitoring of the disease. For self -management patients need adequate knowledge, a variety of skills in various areas related to diabetes like clinical, nutritional, and management that will help in building the right attitude through education. So, educating the patients through digital media will enable us to bring desirable change in the attitude of diabetic patients. With this backdrop, the present paper aimed to assess the 
effectiveness of digital media content on the attitude of the diabetic patients.

\section{Materials and Methods}

An exploratory research design with two hundred type- 2 diabetes respondents were selected randomly from the rural and urban areas of Guntur district of Andhra Pradesh. List of the respondents was collected from three hospitals of Guntur district. Data collected from the respondents by using a prestructured interview schedule. A two months education programme on digital media content like text, voice messages, and animation modules were developed based on the existing gaps in the knowledge, skills and attitude of the respondents towards clinical, nutrition and, management areas of diabetes. For the first-month 8 animation modules disseminated through what's up groups, email and, focused group discussion methods to reach all the respondents. For the second month, a total of 90 text and 30 voice messages were disseminated to all the respondents through bulk message center in the vernacular language. Out of these 31 text messages and 8 voice messages are attitude based. After the education program, postintervention changes in the attitude of the respondents measured with a time gap of two months. A paired t- test was computed to find the significance difference between pre and post intervention.

\section{Results and Discussion}

From the table 1, it was revealed that the respondents had significant progress of positive attitude towards clinical attitude with a percent increase of $23.17 \%$ followed by nutrition attitude $(20.71 \%)$ and management attitude (10\%) after post-intervention. It was apparent from the findings that the respondents reacted positively over the three areas of information that has been disseminated by using different content formats like text, voice, and animation modules. Zhang et al (2019) inferred that the implementation of the self-care program with multimedia software support resulted in improvement in the patient's self-care behavior in the experimental group, but no changes observed in the control group. There exists a significant difference between the mean scores of the test and the control group at pre and post-intervention.

Concerning overall clinical attitude (Table 2) of the respondents after intervention positive attitude found to be high with cent percent variation followed by neutral attitude $(75.28 \%)$ and negative attitude with a percent variation of $36.62 \%$. This could be since the respondents perceived positively about the role of HbAlc test in evaluation of complications, effective control of hyperglycemia with diet, exercise and medication.

With respect to clinical attitude from the Table 3, the respondents had a positive attitude towards $\mathrm{HbA} 1 \mathrm{c}$ test role in evaluating the overall control of diabetes with a percent increase of $30 \%$ followed by control measures for hyperglycemia along with medication, diet $\&$ exercise with an improvement of $23.9 \%$ and persistent hyperglycemia affects vital organs $(15.34 \%)$. The improvement in attitude after the intervention was found to be high due to the dissemination of digital content formats like text, voice, and animation modules. Before the intervention, the respondents had a negative attitude towards HbA1c due to a lack of knowledge about the test. Further, the respondents believed that medication alone was sufficient to control the disease. But, after intervention especially during focused group discussion the study emphasized the importance of diet and exercise based on their glycemic levels in controlling the disease helped in improvement 
of the respondent's attitude. Rasoul et al., (2019) revealed that weblog based self management education has a positive effect on the quality of life of patients of test (56.1) and control group (49.9). Due to increased awareness of diabetes, the patients showed a significant reduction in their fasting blood glucose levels, body mass index, and blood pressure by improving their abilities in managing and treating the disease. Agreeable percent improvement was seen in carrying glucose tablets to treat hypoglycemia (13.12\%) followed by brushing teeth twice in a day to avoid gums problems $(11.93 \%)$ and appropriate footwear with socks to avoid poor circulation $(9.64 \%)$.

Table.1 Overall attitude of the respondents after post intervention $n=200$

\begin{tabular}{|c|l|c|c|c|}
\hline S. No & \multicolumn{1}{|c|}{ Area of Information } & $\begin{array}{c}\text { Pre intervention } \\
\text { mean scores }\end{array}$ & $\begin{array}{c}\text { Post intervention } \\
\text { mean scores }\end{array}$ & \% increase \\
\hline 1. & Clinical attitude & 12.35 & 16.075 & $23.17 \%$ \\
\hline $\mathbf{2 .}$ & Nutrition attitude & 14.55 & 18.35 & $20.71 \%$ \\
\hline $\mathbf{3 .}$ & Management attitude & 16.65 & 18.5 & $10 \%$ \\
\hline
\end{tabular}

Table.2 Overall clinical attitude of the respondent's after post intervention n=200

\begin{tabular}{|c|c|c|c|c|c|}
\hline S. No & Class Interval & Range & Pre intervention (n) & $\begin{array}{c}\text { Post intervention } \\
\text { (n) }\end{array}$ & $\begin{array}{c}\text { \% } \\
\text { variation }\end{array}$ \\
\hline 1. & Negative & $6-10$ & 26 & 17 & $36.62 \%$ \\
\hline $\mathbf{2 .}$ & Neutral & $11-15$ & 174 & 43 & $75.28 \%$ \\
\hline 3. & Positive & $16-20$ & 0 & 143 & $100 \%$ \\
\hline
\end{tabular}

Table.3 Clinical attitude of the respondents from baseline to post intervention $n=200$

\begin{tabular}{|c|l|c|c|c|c|}
\hline S.NO. & \multicolumn{1}{|c|}{ Statements } & \multicolumn{1}{|c|}{$\begin{array}{c}\text { Pre } \\
\text { intervention }\end{array}$} & $\begin{array}{c}\text { Post } \\
\text { intervention }\end{array}$ & $\begin{array}{c}\text { Mean Absolute } \\
\text { Difference } \\
\text { (\% of increase) }\end{array}$ & $\begin{array}{c}\text { Mode of } \\
\text { interventio } \\
\text { n }\end{array}$ \\
\cline { 3 - 6 } & Mean \pm SD & Mean \pm SD & & \\
\hline $\mathbf{1 .}$ & $\begin{array}{l}\text { HbA1C test evaluates overall diabetic } \\
\text { control to make changes necessary }\end{array}$ & $1.855 \pm 0.864$ & $2.65 \pm 0.4475$ & $0.795(30 \%)$ & $2+1+1=4$ \\
\hline $\mathbf{2 .}$ & $\begin{array}{l}\text { Hyperglycemia can be controlled by } \\
\text { regular exercise, medication \& } \\
\text { healthy diet }\end{array}$ & $1.91 \pm 0.711$ & $2.51 \pm 0.559$ & $0.6(23.9 \%)$ & $1+1+1=3$ \\
\hline $\mathbf{3 .}$ & $\begin{array}{l}\text { Persistent hyperglycemia can lead to } \\
\text { complications affecting vital organs } \\
\text { so, lower the blood glucose levels }\end{array}$ & $2.2222 \pm 0.738$ & $2.625 \pm 0.344$ & $0.4028((15.34 \%)$ & $1+1+1=3$ \\
\hline $\mathbf{4 .}$ & $\begin{array}{l}\text { It is better to carry food or glucose } \\
\text { tablets to treat low blood glucose } \\
\text { levels }\end{array}$ & $2.185 \pm 0.660$ & $2.515 \pm 0.4297$ & $0.33(13.12 \%)$ & $1+0+1=2$ \\
\hline $\mathbf{5 .}$ & $\begin{array}{l}\text { Brush teeth twice a day regularly for } \\
\text { healthy teeth \& gums }\end{array}$ & $2.14 \pm 0.800$ & $2.43 \pm 0.565$ & $0.29(11.93 \%)$ & $1+0+0=1$ \\
\hline $\mathbf{6 .}$ & $\begin{array}{l}\text { To avoid poor circulation problems } \\
\text { affecting feet wear socks }\end{array}$ & $2.39 \pm 0.557$ & $2.645 \pm 0.408$ & $0.255(9.64 \%)$ & $1+0+0=1$ \\
\hline & & & & & \\
\hline
\end{tabular}


Table.4 Overall nutrition attitude of the respondents after post intervention $n=200$

\begin{tabular}{|r|l|c|c|c|c|}
\hline S. No & $\begin{array}{l}\text { Class } \\
\text { Interval }\end{array}$ & Range & $\begin{array}{c}\text { Pre intervention } \\
(\mathbf{n})\end{array}$ & $\begin{array}{c}\text { Post intervention } \\
(\mathbf{n})\end{array}$ & \% variation \\
\hline $\mathbf{1 .}$ & Negative & $7-11$ & 24 & 12 & $50.00 \%$ \\
\hline $\mathbf{2 .}$ & Neutral & $12-16$ & 130 & 2 & $98.46 \%$ \\
\hline $\mathbf{3 .}$ & Positive & $17-21$ & 46 & 186 & $75.27 \%$ \\
\hline
\end{tabular}

Table.5 Nutrition attitude of the respondents from baseline to post intervention $n=200$

\begin{tabular}{|c|c|c|c|c|c|}
\hline \multirow[t]{2}{*}{ S.NO. } & \multirow[t]{2}{*}{ Statements } & \multirow{2}{*}{$\begin{array}{c}\text { Pre } \\
\text { intervention } \\
\text { Mean } \pm \text { SD }\end{array}$} & \multirow{2}{*}{$\begin{array}{c}\text { Post } \\
\text { intervention } \\
\text { Mean } \pm \text { SD }\end{array}$} & \multirow[t]{2}{*}{$\begin{array}{l}\text { Mean Absolute } \\
\text { Difference } \\
\text { (\% of increase) }\end{array}$} & \multirow{2}{*}{$\begin{array}{l}\begin{array}{l}\text { Mode of } \\
\text { interven } \\
\text { tion }\end{array} \\
\mathbf{T}+\mathrm{V}+\mathrm{A}\end{array}$} \\
\hline & & & & & \\
\hline 1. & $\begin{array}{l}\text { Eating soluble fiber rich } \\
\text { foods lowers the risk of } \\
\text { elevated blood sugar level } \\
\text { after meals }\end{array}$ & $1.82 \pm 1.154$ & $2.735 \pm 0.668$ & $0.915(33.46 \%)$ & $2+1+1=4$ \\
\hline 2. & $\begin{array}{l}\text { Start meal with low calorie } \\
\text { foods like salads to mange } \\
\text { weight }\end{array}$ & $1.77 \pm 1.102$ & $2.52 \pm 0.685$ & $0.75(30 \%)$ & $2+1+1=4$ \\
\hline 3. & $\begin{array}{l}\text { It is better to eat whole fruits } \\
\text { rather than fruit juices }\end{array}$ & $1.96 \pm 1.040$ & $2.605 \pm 0.651$ & $0.645(24.76 \%)$ & $2+1+1=3$ \\
\hline 4. & $\begin{array}{l}\text { Drink } 10-12 \text { glasses of water } \\
\text { daily to avoid frequent urge } \\
\text { to drink water }\end{array}$ & $2.14 \pm 0.934$ & $2.705 \pm 0.662$ & $0.565(20.89 \%)$ & $1+1+0=2$ \\
\hline 5. & $\begin{array}{l}\text { Restrict sodium rich foods in } \\
\text { diet to avoid hypertension }\end{array}$ & $2.385 \pm 0.841$ & $2.62 \pm 0.681$ & $0.235(8.96 \%)$ & $1+0+0=1$ \\
\hline 6. & $\begin{array}{l}\text { Choose steamed, grilled or } \\
\text { boiled foods over fried foods }\end{array}$ & $2.425 \pm 0.703$ & $2.655 \pm 0.679$ & $0.23(8.66 \%)$ & $1+0+0=1$ \\
\hline 7. & $\begin{array}{l}\text { Indigenous methods to } \\
\text { control blood sugar levels and } \\
\text { cholesterol }\end{array}$ & $2.345 \pm 0.842$ & $2.53 \pm 0.713$ & $0.185(7.31 \%)$ & $1+0+0=1$ \\
\hline
\end{tabular}

Table.6 Overall management attitude of the respondents after post intervention $n=200$

\begin{tabular}{|r|c|c|c|c|c|}
\hline S. No. & Class Interval & Range & $\begin{array}{c}\text { Pre intervention } \\
(\mathbf{n})\end{array}$ & $\begin{array}{c}\text { Post } \\
\text { intervention (n) }\end{array}$ & \% variation \\
\hline $\mathbf{1 .}$ & Negative & $\mathbf{7 - 1 1}$ & $\mathbf{2 0}$ & $\mathbf{1 0}$ & $\mathbf{5 0 \%}$ \\
\hline $\mathbf{2 .}$ & Neutral & $\mathbf{1 2 - 1 6}$ & $\mathbf{5 4}$ & $\mathbf{0}$ & $\mathbf{1 0 0 \%}$ \\
\hline $\mathbf{3 .}$ & Positive & $\mathbf{1 7 - 2 1}$ & $\mathbf{1 2 6}$ & $\mathbf{1 9 0}$ & $\mathbf{3 2 . 6 5 \%}$ \\
\hline
\end{tabular}


Table.7 Management attitude of the respondents from baseline to post intervention $n=200$

\begin{tabular}{|c|c|c|c|c|c|}
\hline \multirow[t]{2}{*}{ S.NO. } & \multirow[t]{2}{*}{ Statements } & Pre intervention & $\begin{array}{c}\text { Post } \\
\text { intervention }\end{array}$ & \multirow{2}{*}{$\begin{array}{c}\text { Mean } \\
\text { Absolute } \\
\text { Difference } \\
\text { (\% of } \\
\text { increase) }\end{array}$} & \multirow{2}{*}{\begin{tabular}{|c|c|}
$\begin{array}{c}\text { Mode of } \\
\text { interventi } \\
\text { on }\end{array}$ \\
$\mathbf{T}+\mathbf{V}+\mathbf{A}$ \\
\end{tabular}} \\
\hline & & Mean $\pm S D$ & Mean $\pm S D$ & & \\
\hline 1. & $\begin{array}{l}\text { Avoid diabetic complications } \\
\text { by checking eyes, urine, } \\
\text { cholesterol tests once in a year }\end{array}$ & $1.995 \pm 1.073$ & $2.615 \pm 0.688$ & $\begin{array}{l}0.62 \\
(23.71 \%)\end{array}$ & $3+0+1=4$ \\
\hline 2. & $\begin{array}{l}\text { Avoid foods high in added } \\
\text { sugar like sweets and soft } \\
\text { drinks }\end{array}$ & $2.39 \pm 0.8703$ & $2.785 \pm 0.586$ & $\begin{array}{l}0.395 \\
(14.18 \%)\end{array}$ & $2+0+1=3$ \\
\hline 3. & $\begin{array}{l}\text { Regular exercise enhances the } \\
\text { health status by controlling } \\
\text { sugar levels }\end{array}$ & $2.32 \pm 0.884$ & $2.685 \pm 0.655$ & $\begin{array}{l}0.365 \\
(13.59 \%)\end{array}$ & $3+0+0=3$ \\
\hline 4. & $\begin{array}{l}\text { Diabetes mellitus is treatable } \\
\text { with dietary practices and } \\
\text { exercise and medication. }\end{array}$ & $2.185 \pm 0.959$ & $2.48 \pm 0.763$ & $\begin{array}{l}0.295 \\
(11.9 \%)\end{array}$ & $1+1+0=2$ \\
\hline 5. & $\begin{array}{l}\text { To reduce weight, one should } \\
\text { manage the diet }\end{array}$ & $2.215 \pm 0.947$ & $2.495 \pm 0.768$ & $\begin{array}{l}0.28 \\
(11.22 \%)\end{array}$ & $2+0+0=2$ \\
\hline 6. & $\begin{array}{l}\text { Cooking in non stick utensils } \\
\text { consume less oil }\end{array}$ & $2.53 \pm 0.761$ & $2.755 \pm 0.579$ & $\begin{array}{l}0.225 \\
(8.17 \%)\end{array}$ & $1+0+0=1$ \\
\hline 7. & $\begin{array}{l}\text { Cook at home with fresh and } \\
\text { healthy ingredients to stay } \\
\text { healthy }\end{array}$ & $2.47 \pm 0.838$ & $2.665 \pm 0.707$ & $\begin{array}{l}0.195 \\
(7.32 \%)\end{array}$ & $1+0+0=1$ \\
\hline
\end{tabular}

Table.8 Change in attitude of the respondents after post intervention

\begin{tabular}{|l|l|l|l|l|}
\hline S. No. & $\begin{array}{l}\text { Mean Post } \\
\text { Intervention }\end{array}$ & $\begin{array}{l}\text { Mean Pre } \\
\text { intervention }\end{array}$ & $\begin{array}{l}\text { Mean Difference } \\
\text { (\% increase) }\end{array}$ & $\begin{array}{l}\text { Paired t-test result } \\
\text { p-value }\end{array}$ \\
\hline 1. & 17.64167 & 14.51667 & $3.125(17.71 \%)$ & 0.039 \\
\hline
\end{tabular}

The table 4 indicated that, the overall nutrition attitude of the respondents improved significantly. The respondents had a neutral attitude with a mean percent variation of $98.46 \%$ followed by a positive attitude $(75.27 \%)$ and a negative attitude (50\%). A high need for nutrition-related information helped to improve the attitude of the respondents after intervention through different digital initiatives. Salahshouri et al., (2018) inferred that the mean score of sub group's perceptions and beliefs were significantly higher than control group after three months of intervention. Further the sub groups negative feelings, such as fear and discomfort found to be reduced after education intervention, and their adherence to the healthy diet improved. Saleh et al., (2017) revealed that the attitude of diabetic patients to take the advice of dieticians, having food at the same time every day \& weighing of food have been changed significantly from preintervention to post-intervention. 
From the Table 5 it can be seen that, profoundly noteworthy percent of the respondents perceived positively after the intervention about the role of soluble fiber in lowering the blood sugar levels $(33.46 \%)$ followed by low-calorie foods (30\%), choosing fruits over fruit juices $(24.76 \%)$ and drinking adequate water to control polydipsia $(20.89 \%)$. The reason for this might be that the information disseminated related to these aspects brought a consciousness towards blood sugar and weight management. Further fiber role and weight managed tips are in more number of animated modules along with text \& voice messages aid in behavioral change. Some of the text messages related to these statements were Beans rich in soluble fibers lowers the risk of elevated blood sugar levels after meals. Manage weight- start a meal with foods that are low in calories like salads. By the time one gets to other foods, one won't be hungry. Dietary fiber in the diet increases insulin sensitivity; take a whole apple instead of juice. Polydipsia is the urge to drink more water. Do not drink sugary drinks. Drink 10-12 glasses of water daily. All these messages are narrated in such a manner that it would motivate the respondents to induce action. Bruis et al., (2013) indicated that SMS has a positive perception and brings positive behavior change. The respondents in the study agreed that messages were clear and easy to understand and had brought behavior changes related to diet. More than three fourth of the respondents readily agreed to replace concentrated sugar-based drinks such as preserved juices, soda. The majority of respondents $(74.2 \%)$ preferred to have whole fruits instead of desserts, $76.1 \%$ preferred to buy healthier foods, and $75.5 \%$ indicated to eat more grilled, baked, or broiled foods instead of fried.

A relatively less percent increase was seen among restriction of sodium-rich foods, choosing the right choice foods, and motivating towards accepting some indigenous methods $(8.96 \%, 8.66 \%, \&$ $7.31 \%$ ) respectively. Only one text message that was sent related to each statement might be the reason for low percent improvement and individual preferences towards these statements might be the reason. For instance, accepting indigenous methods like drinking one tablespoon of fenugreek seeds, eating crushed garlic to reduce cholesterol levels might be difficult to follow and accept.

The above table 6 reveals that, cent percent variation of neutrality to fifty percent variation of negativity to $32.65 \%$ positivity towards the management attitude of the respondents. From these findings, it was evident that the respondents perceived positively about the aspects related to management after the intervention, and their negative attitude towards management aspects decreased to fifty percent after the intervention. But the neutral attitude towards the management area remained unchanged, due to personal variables like other health issues and educational status of the respondents even after the educational intervention.

A significant percent increase of positive attitude was observed from the table 7 , about the referral services related to diabetes (23.71\%) followed by avoiding foods high in added sugars (14.18\%) and benefits of exercise in controlling the disease (13.59\%). A considerable percent of attitude improvement was found in the statements like diabetes is treatable $(11.9 \%)$, weight reduction by diet management (11.22\%), cooking in nonstick utensils $(8.17 \%)$ and home-based foods $(7.32 \%)$. The reason for the highest percent increase after the intervention may be due to repeated text messages about checkups related to eyes, urine, and cholesterol as they have an impact on the functioning of vital organs like kidney, 
heart, and eyes. The mean diabetic age of the respondents was 8.02 years, so most of the respondents wanted to be careful to prevent future complications. Hence they were positively responded after intervention though text messages and animation through focused group discussion.

Garima (2016) reported that the diabetic patient's attitude towards monitoring blood glucose levels, keeping candies to avoid hypoglycemia, and avoiding the harmful effects of the excessive exercise was, lacking before the education program. But, after the education program, the patient's attitude about various aspects of hypoglycemia has been improved and the patient's attitude towards timely intake of meals and the importance of regular medication has been improved. Similar results were inferred by Chawla et al., (2019) and Didarloo et al., (2020) also.

An inference could be drawn from the above table 8 that, there was a significant difference of 3.12 in the overall attitude of the respondents before and after the intervention as $t$ value was found significant at 0.05 level of probability. Thus, the null hypothesis was rejected and the empirical hypothesis may be accepted.

The respondents responded positively to the information disseminated through digital media as the content delivered was in a more convincing and thought provoking manner. Muchiri et al., (2016), indicated that the patient's mean score knowledge on diabetes among the intervention group was higher in the intervention group compared to the control group after 6 and 12 months of intervention and the scores were below $50 \%$. But, the patient's attitude towards diabetes was significantly higher at 12 months. Similarly Farahani et al., (2016) and Andriyanto (2019) reported that there was remarkable improvement of mean attitude of the diabetic patients after education programmes.

It could be concluded from the study that the patient's perception of diabetes is associated with several myths due to a lack of adequate awareness at the pre-intervention level. So, appropriate education about the disease enhanced their knowledge about the disease that in turn, resulted in changing their attitude for effective self-care management of the disease. Hence, educating the patients through digital media content formats such as text, voice messages, and animation modules in vernacular language is one of the effective platforms of today's technology-driven society to comprehend and improve their psychological acceptance of the disease.

\section{References}

Andriyanto, A., Rekawati, E. and Rahmadiyah, D.C., 2019. Increasing Knowledge, Attitudes, Skills, and Glucose Control in Type-2 Diabetic Patients through EMAS Interventions. Nurse Media Journal of Nursing, 9(2), pp. 141-150.

Bruis, R.L., Hirzel, L. Turske, A.S., Jardines, D. R.T., Yarandi, H. Bondurant, P. 2013. Use of a Text Message Program to Raise Type 2 Diabetes Risk Awareness and Promote Health Behavior Change (Part II): Assessment of Participants' Perceptions on Efficacy. Journal of JMIR. 15(12)1 - 9.

Chawla, S.P.S., Kaur, S., Bharti, A., Garg, R., Kaur, M., Soin, D., Ghosh, A. and Pal R. 2019. Impact of health education on knowledge, attitude, practices and glycemic control in type 2 diabetes mellitus. Journal of Family Medicine and Primary Care. 8(1), p.261.

Didarloo, A., Shojaeizadeh, D. and Alizadeh, 
M., 2016. Impact of educational intervention based on interactive approaches on beliefs, behavior, hemoglobin A1c, and quality of life in diabetic women. International Journal of Preventive Medicine, 7.

Farahani, M.F., Purfarzad, Z., Ghorbani, M., Zare, Z.G. and Ghorbani, F., 2016. The impact of multimedia software support on the knowledge and selfcare behaviors of patients with type 2 diabetes: A Randomized Clinical Trial. Journal of Caring Sciences, 5(2), p.111.

Garima B., Sanjay K., Sonika L., Prem Kumar Verma, Rahul S., Meenakshi G.. 2016. Effect of diabetic education on the knowledge, attitude and practices of diabetic patients towards prevention of hypoglycemia. Indian Journal of Endocrinology and Metabolism. Vol 19. Issue 3.

Muchiri, J.W., Gericke, G.J. and Rheeder, P., 2016. Impact of nutrition education on diabetes knowledge and attitudes of adults with type 2 diabetes living in a resource-limited setting in South Africa: a randomised controlled trial. Journal of Endocrinology,
Metabolism and Diabetes of South Africa, 21(2), pp.26-34.

Rasoul, A.M., Jalali, R., Abdi, A., Salari, N., Rahimi, M. and Mohammadi, M., 2019. The effect of self-management education through weblogs on the quality of life of diabetic patients. BMC Medical Informatics and Decision Making, 19(1), p. 205.

Salahshouri, A., Alavijeh, F.Z., Mahaki, B. and Mostafavi, F., 2018. Effectiveness of educational intervention based on psychological factors on achieving health outcomes in patients with type 2 diabetes. Diabetology \&Metabolic Syndrome, 10(1), p.67.

Saleh, F., Afnan, F., Ara, F., Mumu, S.J. and Khan, A.A., 2017. Diabetes education, knowledge improvement, attitudes and self-care activities among patients with Type 2 Diabetes in Bangladesh. Jundishapur Journal of Health Sciences, 9(1).

Zhang, Z., Monro, J. and Venn, B.J., 2019. Development and Evaluation of an Internet-Based Diabetes Nutrition Education Resource. Nutrients, 11(6), p.1217.

\section{How to cite this article:}

Padmini Devi, G. 2020. Effectiveness of Digital Media Education on the Attitude of the Diabetic Patients. Int.J.Curr.Microbiol.App.Sci. 9(09): 1116-1123. doi: https://doi.org/10.20546/ijcmas.2020.909.139 